\title{
The Minories Eagle: A New Sculpture from London's Eastern Roman Cemetery
}

\author{
By ANTONIETTA LERZ, MARTIN HENIG and KEVIN HAYWARD
}

\begin{abstract}
The limestone sculpture of an eagle firmly clasping a serpent in its beak was recovered from within the eastern Roman cemetery of London on the last day of excavations at 24-26 Minories, EC3 in September 2013. The sculpture, which is dated stylistically to the late first or early second century A.D., had been carefully buried within the backfill of a roadside ditch no later than the mid-second century. The Minories eagle is one of the finest and earliest examples of freestone sculpture from the London cemeteries and presumably adorned the tomb of a rich and important individual or family located nearby. Petrological analysis of the sculpture has revealed it is carved from oolitic limestone quarried from the south Cotswolds. The article presents the context of the findspot and a detailed description of the eagle sculpture with an in-depth discussion of the iconography of the image and the results of the petrological examination. The Supplementary Material available online (http://journals.cambridge.org/bri) presents an account of the site stratigraphy, integrated with the specialist finds and the environmental reports.
\end{abstract}

Keywords: Roman London; stone sculpture; eagle and serpent; eastern Roman cemetery; roadside ditch; mausoleum; petrological examination

\section{INTRODUCTION}

$\mathrm{I}$ $\mathrm{n}$ the spring and summer of 2013 Museum of London Archaeology (MOLA) undertook a developer-funded excavation of the site of 24-26 Minories, within the City of London, EC3N (site code: MNR12, NGR 533660 181065) (FIG. 1). Redevelopment of the site comprised the demolition of a 1960s office block to make way for a 16-storey hotel by investor Aberdeen Asset Management and developer Endurance Land.

On the last day of the excavations, the stone sculpture of an eagle and serpent was recovered from the fill of the roadside ditch in the south-east corner of the site. The sculpture was initially displayed in the Museum of London and published in the Corpus of Roman Sculpture from London and the South-East. ${ }^{1}$ The purpose of this paper is to provide further information on the sculpture: the contextual background of the find, an in-depth discussion of the iconography of the sculpture and the results of the petrological examination.

$1 \quad$ Coombe et al. 2015, 124-6. 
The sculpture comes from within the cemetery located east of the Roman town and is an important addition to the body of religious and funerary stone sculptures from London. While there is ample evidence for funerary structures such as mausolea and monuments, freestanding sculpture from the eastern cemetery, and indeed the London cemeteries as a whole, is rare. ${ }^{2}$ In the late third and fourth centuries considerable robbing of funerary monuments took place for incorporation into the late Roman defences. London's cemeteries provided a local and immediate source of cut stone, perhaps from tombs and monuments that had long since been unattended. These include the tombstone of a young girl, Marciana, recovered from Bastion 4 at Crosswall, Vine Street, ${ }^{3}$ near the southern limit of the eastern cemetery, and part of the funerary inscription from the tomb of the first-century procurator Julius Classicianus, found in the bastion at Tower Hill. ${ }^{4}$ The tomb is likely to have been located in the eastern cemetery, though its precise location is, of course, unknown. The distinct advantage of the Minories eagle is that it is stratified and likely to have been situated locally.

The remarkable state of preservation of the eagle makes it one of the best examples of sculpture surviving from Roman London but it is extremely fortunate that it has come down to us at all. Only two sections of the ditch survived in the central and south-eastern part of the site, the rest having been removed by medieval and post-medieval cesspits and cellars or modern basements and piling which destroyed large areas of the Roman sequence. ${ }^{5}$

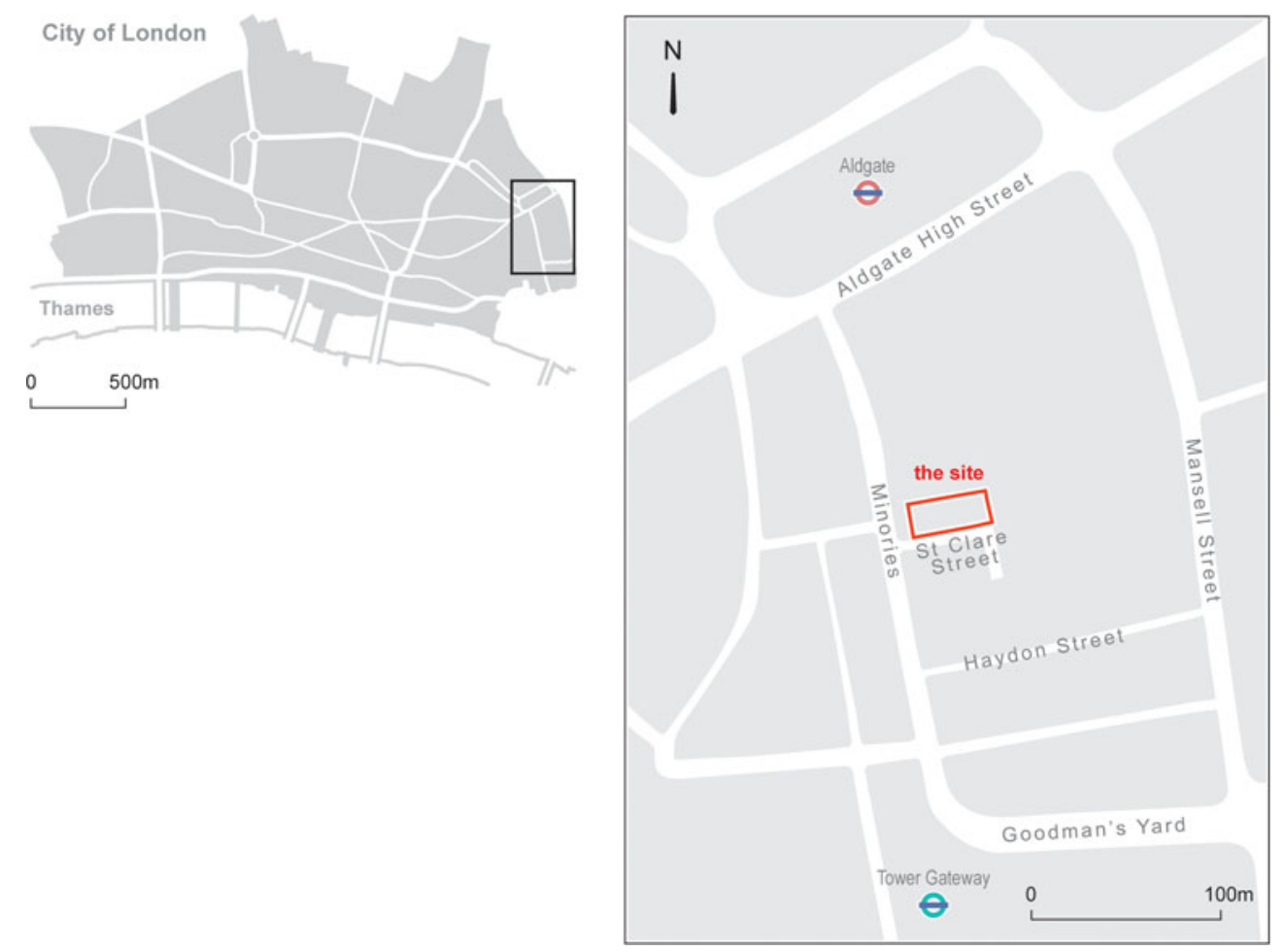

FIG. 1. Site location (scale 1:5,000).

\section{Perring 1991, 93.}

Coombe et al. 2015, no. $84=$ RIB III, 3003.

Marsden 1980, 171-2; Maloney 1983, 115.

5 The post-Roman development of the site is described in Lerz et al., forthcoming. 


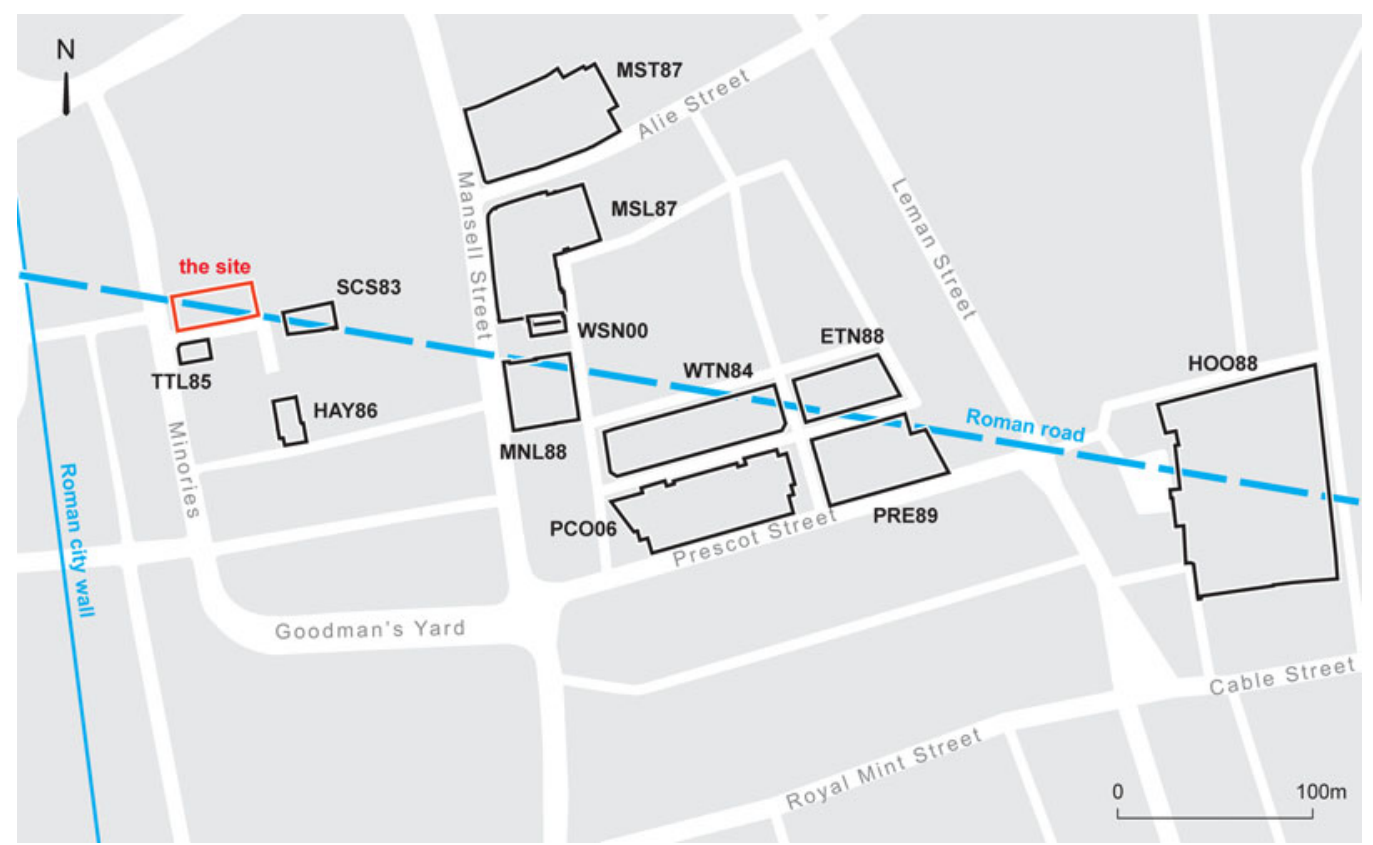

FIG. 2. The location of MNR12 in relation to sites excavated in the cemetery east of the Roman city along the course of the access road (scale 1:5,000).

\section{THE CONTEXT OF THE FIND}

The site is located some $200 \mathrm{~m}$ east of the third-century A.D. Roman city defences on the route of the cemetery road (FIG. 2). The eastern cemetery is thought to have been established around the end of the first or beginning of the second century A.D. and continued in use into the fifth century. ${ }^{6}$

The excavations revealed the course of the cemetery road and its north-flanking ditch running roughly on the east-west alignment projected from nearby sites. ${ }^{7}$ The road appears to have been in use by A.D. 69-96 judging from the finds recovered in its associated north-flanking ditch and remained in use until the fourth century. The first-century road is contemporary with a small number of gullies and ditches which may have divided the cemetery area into burial plots, as seen elsewhere in the cemetery, ${ }^{8}$ but only a small cluster of pits and dumps survived within their boundaries (FIG. 3).

The ditch was recut on two occasions: firstly at the turn of the second century and a second time before the mid-third century. Following the backfilling of the first-century ditch, a square mausoleum or funerary monument with stone foundations was built up against its north bank. Nearby lay the chalk-lined burial of an adult female, perhaps located together with the

\footnotetext{
6 Marsden 1980, 24.

7 It follows the alignment of the road uncovered at the neighbouring site of 9 St Clare Street (Ellis 1985; site code SCS83). The following sites used in the report are shown in FIG. 2: ETN88 East Tenter Street, E1; HAY86 13 Haydon Street, EC3; H0088 Hooper Street, E1; MNL88 65-73 Mansell Street, E1; MSL87 49-55 Mansell Street, E1; MST87 7-43 Mansell Street, E1; PCO06 41-63 Prescot Street; PRE89 63-66 Prescot Street; SCS83 9 St Clare Street; TTL85 The Three Lords Public House, 27 Minories, EC3; WSN00 25 West Tenter Street, E1; WTN84 West Tenter Street, E1.

8 Barber and Bowsher 2000, 51-2.
} 


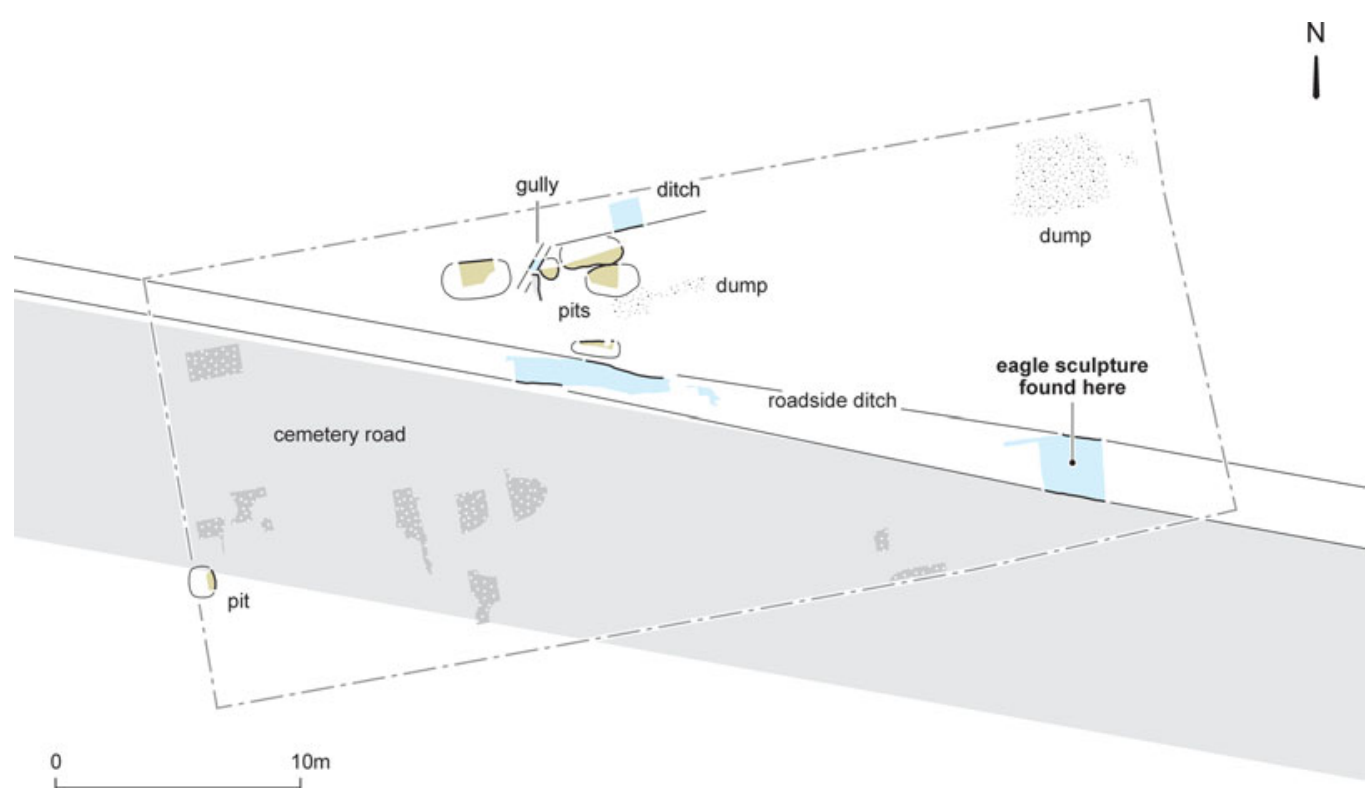

FIG. 3. The site in the second century A.D. showing the location of the eagle sculpture in the roadside ditch (scale $1: 400)$.

mausoleum in a roadside family plot. The latest inhumation on the site was the late Roman burial of a young adult dated A.D. 250-400. Further details of these burials are discussed in the online supplementary material, where the Roman narrative is presented together with a description of the ceramics, finds and environmental material.

The eagle-and-serpent sculpture was recovered from the fill of the late first-/early second-century roadside ditch (FIG. 3). The eagle was carefully placed in the ditch and covered with a thick sandy deposit; a small contemporary group of ceramics dates the deposition of the sculpture to the period A.D. 120-60. The date of the associated finds suggests that the sculpture was buried not very long after it was carved. Some effort was made to dispose of it carefully, though there is nothing to suggest that the sculpture and these items were deliberately placed together.

\section{THE MINORIES EAGLE: A MASTERPIECE OF SOUTH COTSWOLD SCULPTURAL ART By Martin Henig}

The eagle $<$ S $1>$ (FIGS 4-8) is carved in the round, though the rear of the sculpture lacks the careful detailing of the front, and the eagle's wings are somewhat curved on the upper side, which suggests that it fitted into a niche. ${ }^{9}$ The right wing was broken off at the time of discovery and the left eye of the bird has sustained slight damage. Height: $0.66 \mathrm{~m}$; Width: $0.55 \mathrm{~m}$ (including wings); $0.46 \mathrm{~m}$ (without wings); Depth: $0.23 \mathrm{~m}$.

The statue depicts an eagle, with wings partially spread, shown frontally but with its head turned in profile to the left. It has powerful talons with three segmented toes on each foot in front, each with a claw which clutches the low base on which the bird is mounted. The eagle firmly clasps a very long, writhing serpent in its beak. 


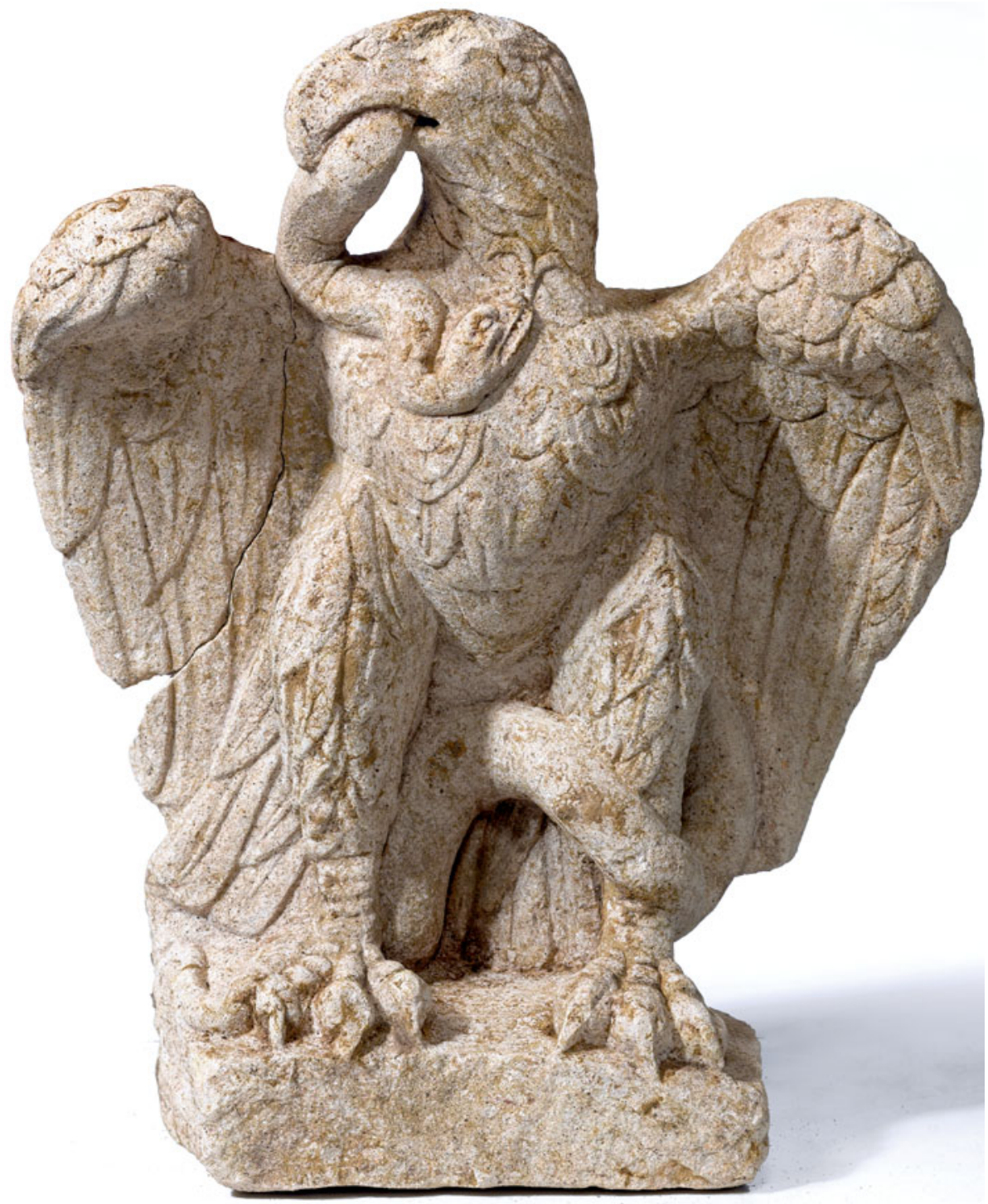

FIG. 4. Front view of the eagle and serpent sculpture $<$ S $1>$, height $0.66 \mathrm{~m}$.

On the front both bird and snake are meticulously carved in a yellowish oolitic Cotswold limestone (see Hayward, below). The eagle's plumage consists of feathers of varying length and profile. There are short ovoid ones with prominent central spine in the region of the neck which rather resemble the imbrication which is often to be seen on column shafts, so called from its resemblance to overlapping roof-tiles, reminiscent in form of the laurel leaves on the bolsters of Classicianus' near-contemporary tomb monument. ${ }^{10}$ Their length increases lower down and especially in the wings which terminate in long slightly curving pinions. Their rich

10 cf. Blagg 2002, 72-3; Coombe et al. 2015, 49, no. 82. 


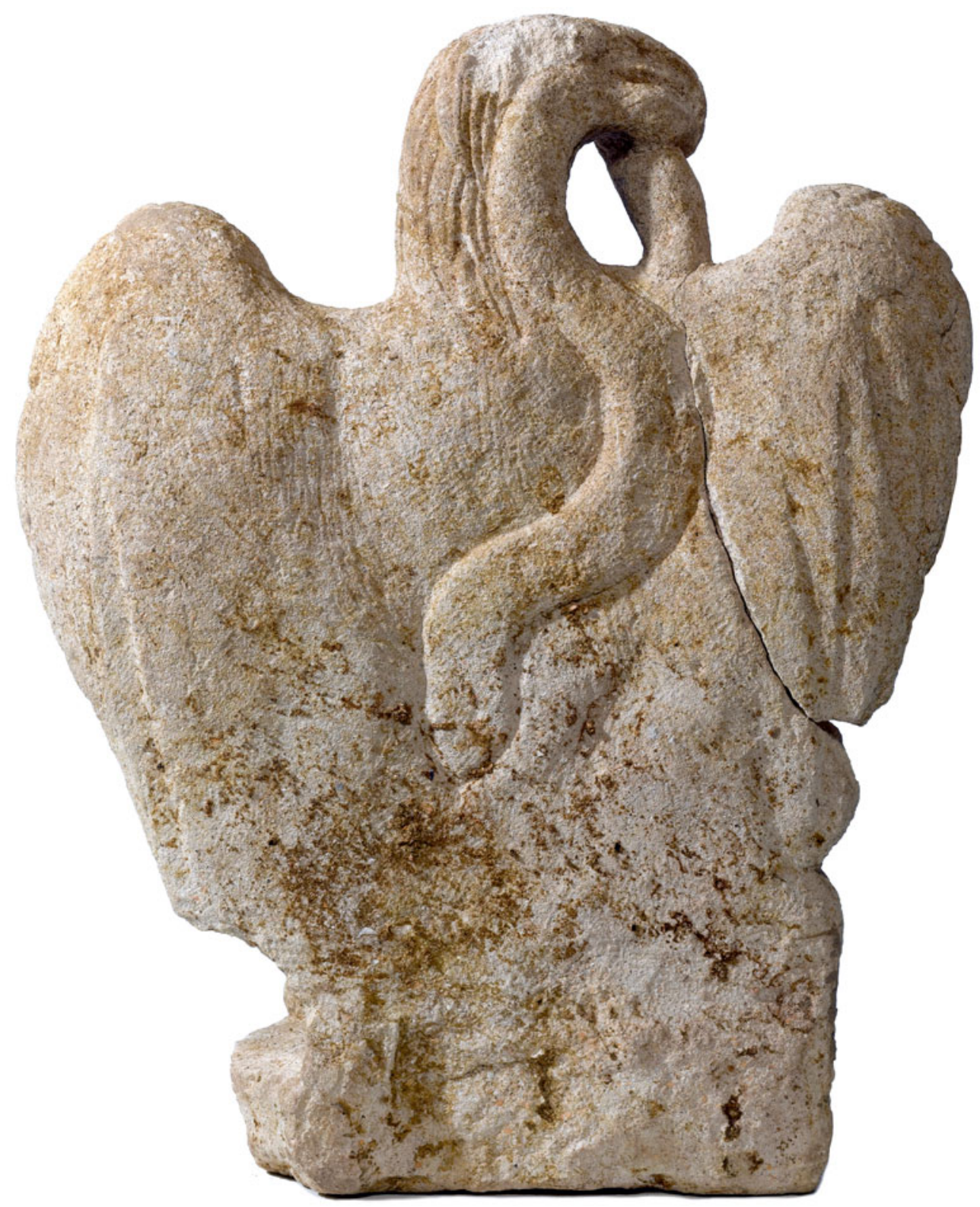

FIG. 5. Back view of the eagle $<\mathrm{S} 1>$, showing the outline of the serpent, height $0.66 \mathrm{~m}$.

texture is characteristic of the Flavian-Trajanic period and may be compared with the masterly carving of the wings of the Colchester sphinx or the wings in the hair of the gorgon on the pediment of the Temple of Sulis Minerva at Bath. ${ }^{11}$ While the body of the serpent is less

11 Huskinson 1994, 30, no. 63 (Colchester); Cunliffe and Fulford 1982, 11, nos 32-7; Cunliffe and Davenport 1985, 115-16, pl. xxxviii (Bath gorgon). 


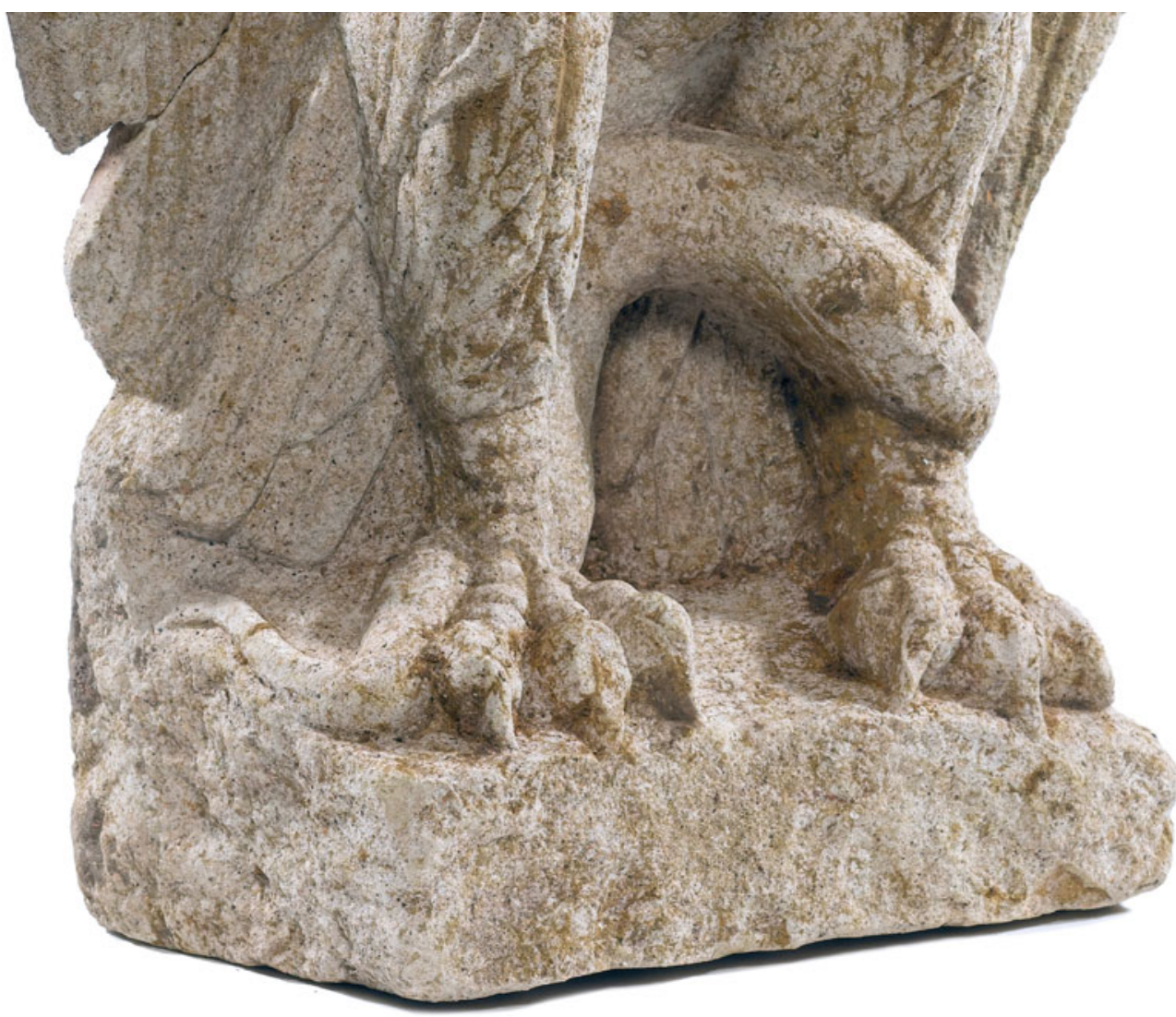

FIG. 6. Side detail of lower left (facing) to show the curving tail of the serpent and the claws of the eagle.

detailed, its expressive head and exaggeratedly forked tongue, so suggestive of malice, is the creation of a very accomplished sculptor. There has been no attempt to detail the back of the sculpture, either to indicate the eagle's plumage or the writhing body of the snake, though the body of the snake is portrayed winding under the eagle's left wing, with its head and neck emerging only to be seized by its adversary.

The sculpture appears somewhat curved seen from the back probably to allow it to fit snugly in an alcove or niche. The sculpture stands on a low rectangular base. Comparison may be made with the low base of the much later, third-century sculpture of a boy from Westminster carved from a French limestone, which was most probably likewise a funerary sculpture from within a mausoleum. ${ }^{12}$ It is probable that the eagle would have stood upon a plinth, perhaps containing a receptacle for the ashes of the deceased in a setting similar to that in the tomb of Sabinus Taurius at Isola Sacra. ${ }^{13}$ An inscription commemorating the deceased might well have been affixed to this stand.

Eagles were pre-eminently the cult bird of Jupiter and the much smaller (and less well-executed) carvings of eagles from the Gloucestershire Cotswolds, from Cirencester, 


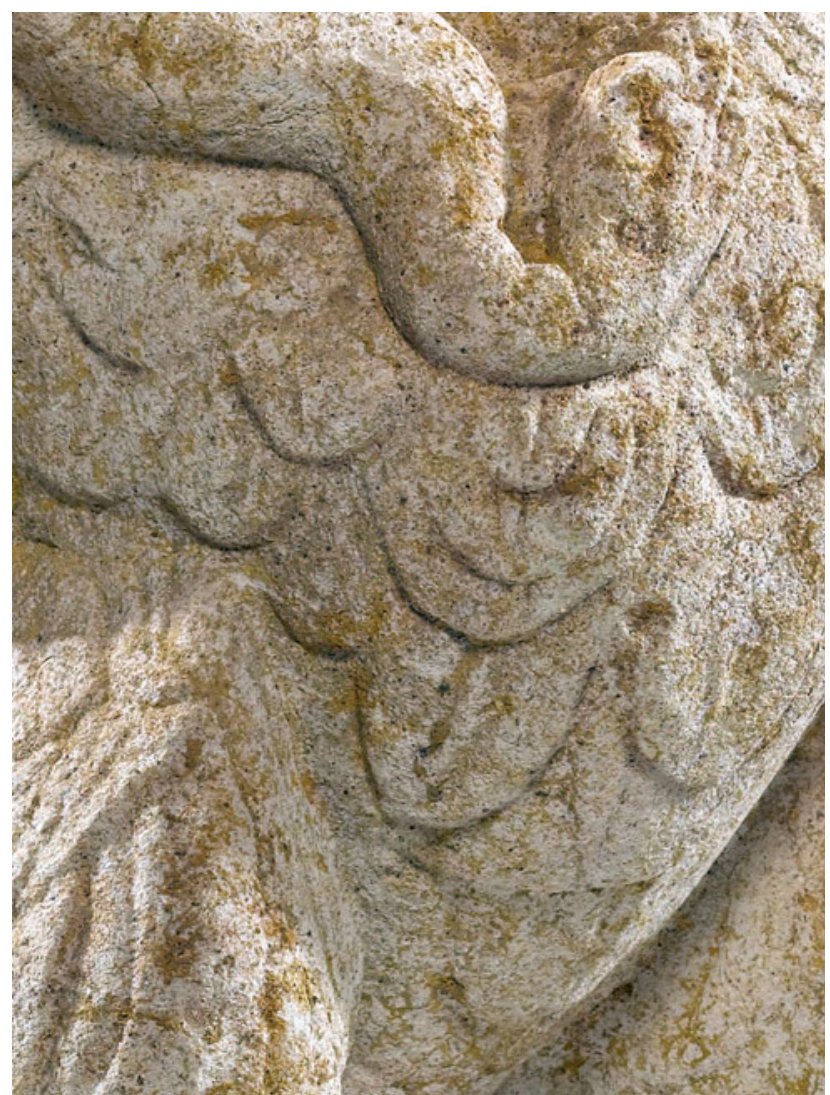

FIG. 7. Detail of the chest feathers showing imbrication.

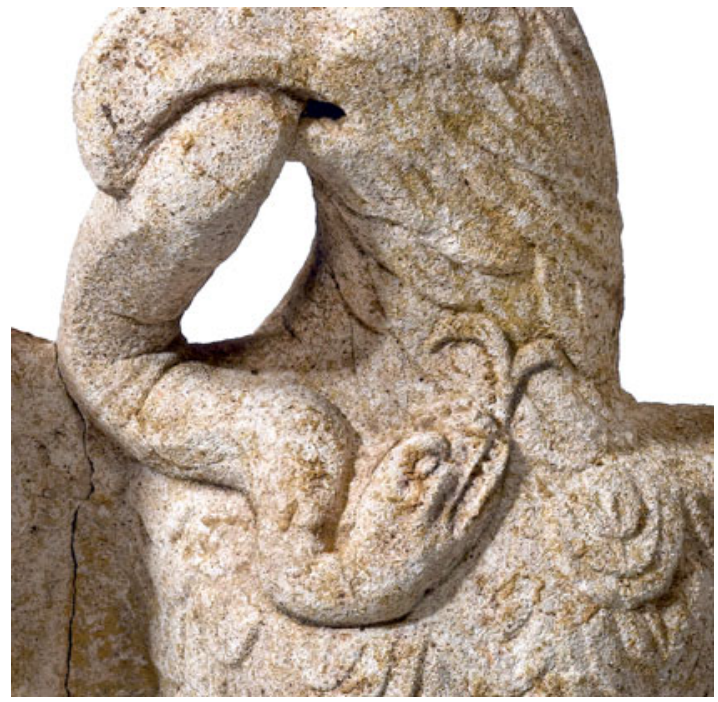

FIG. 8. Detail of the serpent's head with tongue. 
Somerford Keynes and Spoonley Wood, all very probably accompanied images of the god. ${ }^{14}$ A Purbeck marble sculpture of an eagle, shown facing and carved in relief, was excavated at the mid-first-century fortress of legio II Augusta at Exeter and is probably of Neronian date. The bird is depicted frontally and unfortunately now lacks its head and lower legs, but the plumage is skilfully delineated. ${ }^{15}$

Fully in the round and much smaller than these, albeit as finely detailed as the Minories eagle and of about the same date, is the cast copper-alloy eagle from the site of the Basilica at Silchester, in a context which can now be dated no later than the early second century (FIG. 9a). ${ }^{16}$ The wings of this eagle were spread above its back, probably extending above its head, but though its stance may have been a little different from that of the Minories eagle, the rich plumage suggests it was a product of the same Neronian-Flavian period. It is probable that the Silchester eagle was an attribute of a half-length statue of Jupiter, represented either standing or seated, possibly perched upon his hand or standing by his side. It most probably graced a shrine within an important public building, perhaps a predecessor of the Hadrianic-Antonine basilica.

Although the eagle associated with Zeus/Jupiter is conventionally identified as the Golden Eagle (Aquila chrysaetos), it is probable that in this case the eagle is in fact the Short-toed Eagle (Circaetus gallicus) which prefers a warm, dry climate and currently occurs in southern France, Spain, Portugal, North Africa and around the Mediterranean and formerly also in Western Europe (though not Britain) and eastwards to India. This species feeds very largely on reptiles with a preference for snakes, particularly non-venomous species. ${ }^{17}$

There is only one other sculpture known to the author of a freestanding eagle entwined by a serpent from Britain, a fragmentary carving from Somerset originating from either the Keynsham or Somerdale villa. ${ }^{18}$ Although Cunliffe and Fulford recognised the snake, it was left to Anthony Beeson to note that the snake was curled around the eagle. ${ }^{19} \mathrm{He}$ saw it as an insular version of two Nabataean statues from Khirbet Tannur and Zaharet el-Bedd in Jordan on the extreme east of the Empire, which differ from the Minories statue in that the eagle in these instances is not about to eat the snake which there represents an aspect of the Nabataean solar deity Zeus Hadad (FIG. 9b). ${ }^{20}$ Shortly after the Minories eagle was discovered, Beeson immediately published a further short paper pointing out the similarity of the Minories eagle to those from Jordan and suggesting that, as in those sculptures, the snake was to be regarded as beneficent and that 'the Minories eagle should be seen as victorious not against evil but against the underworld that the snake represents, and where mortal souls were expected to go after death' ${ }^{21}$ Here he is surely wrong, at least iconographically, for the Minories eagle is surely about to kill and perhaps eat the villainous-looking, fork-tongued snake, though it is more than likely that the Minories eagle and the later Nabataean variant had a common, probably Augustan, prototype of the later first century B.C. The Minories sculpture would appear far more 'classical' as an image, closer in detail and in date to that prototype which takes its place in a long sequence of images of an eagle (the symbol of the chief of the gods, Zeus or Jupiter) in conflict with a serpent (here representing death and evil forces). Csaba Szabó has provided plausibility to such an interpretation by pointing out a dedication to Jupiter from Apulum (Alba Iulia) in Dacia reading:

Henig 1993, 56-7, nos 166-8.

ibid., 83-4, no. 3 .

Durham 2013.

Information from Alan Pipe.

Cunliffe and Fulford 1982, 40, no. 143.

Beeson 2003.

Glueck 1966, 479-85, pls 140-1.

Beeson 2014. 
a

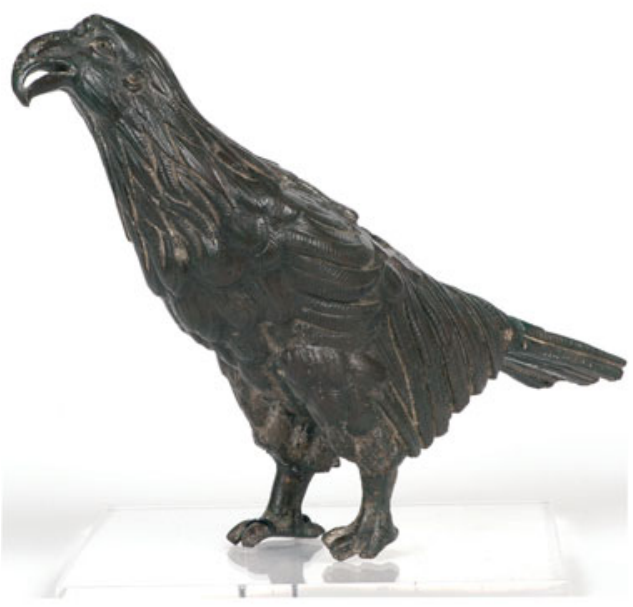

c

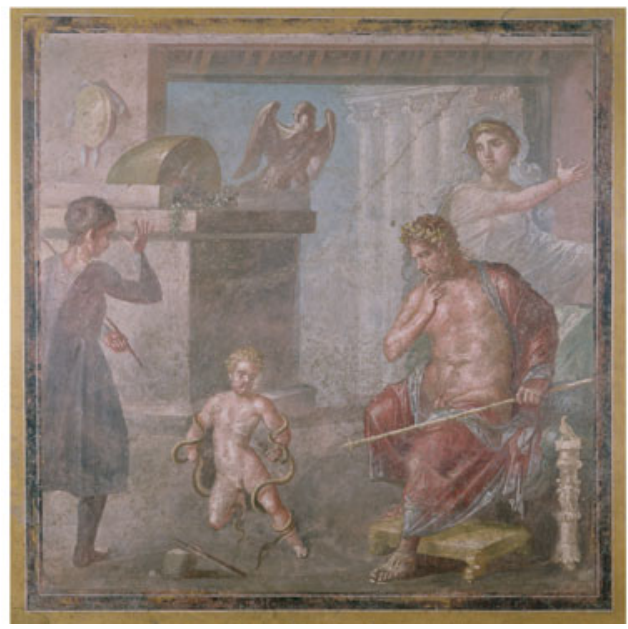

b

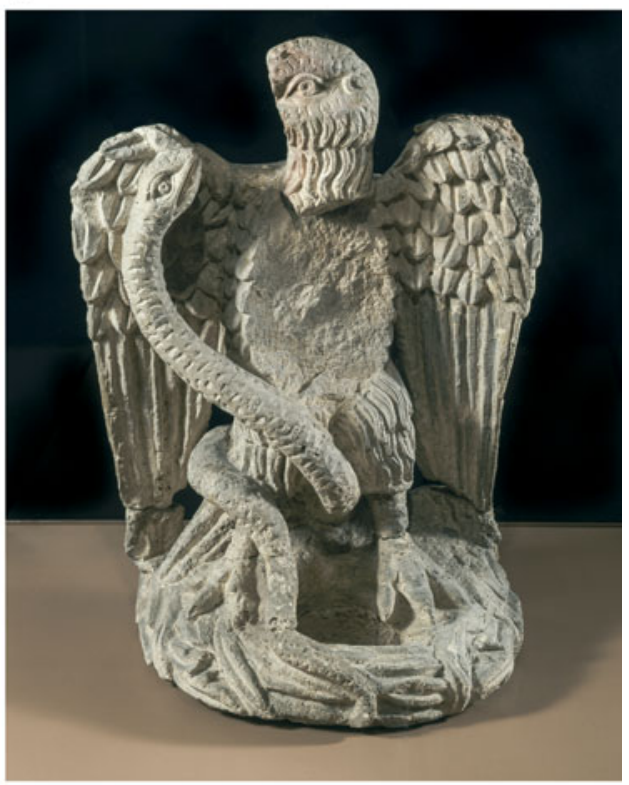

d

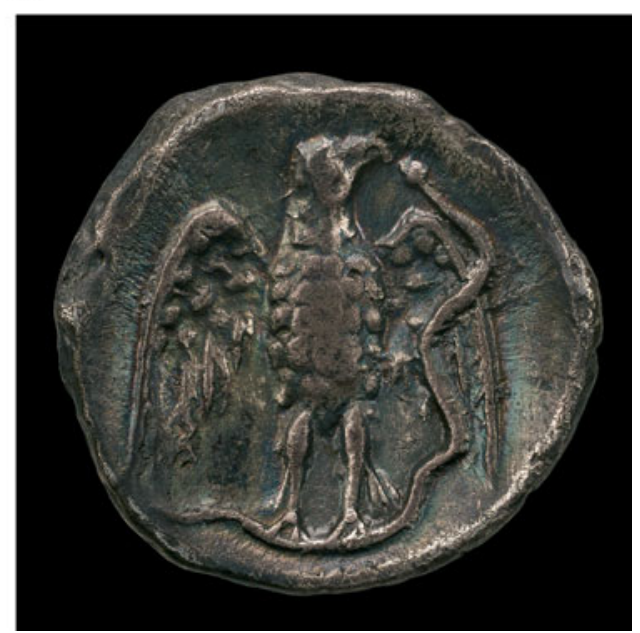

FIG. 9. Four comparative images for the eagle or eagle and serpent: (a) the Silchester bronze eagle (C Reading Museum (Reading Borough Council)); (b) eagle and snake statue from Khirbet et Tannur, Jordan (Cincinnati Art Museum, Ohio, USA; (c) Bridgeman Images); (c) Hercules strangling the serpents as a child, from the Casa dei Vettii, Pompeii c. A.D. 50-79 (fresco) (Pompeii, Italy; (C) Bridgeman Images); (d) small silver unit of Tincomarus; the reverse depicts a spread eagle and rearing snake (C) The Trustees of the British Museum). 
I(ovi) o(ptimo) m(aximo) / Aur(elius) Marinus / Bas(s)us et Aur(elius) / Castor Polyd/ $i$ circumstantes / viderunt numen / aquilae descidis(s)e / monte supra dracone(m) / res validavit / supstrinxit aquila(m) / hi s(upra) s(cripti) aquila(m) de / periculo / liberaverunt / $v$ (oto) l(ibentes) m(erito) $p$ (osuerunt). ${ }^{22}$

With slight emendation po(ntem) Lyd/i for Polyd/i, it might be translated:

To Jupiter Optimus Maximus, Aurelius Marinus Bassus and Aurelius Castor, standing by the bridge of Lydus, saw the numen ('divine spirit') of an eagle descend from the mountain upon a draco (serpent). But the strength of the snake was so powerful that it overcame the eagle. Those inscribed above freed the eagle from danger and freely set this up in fulfilment of a vow. ${ }^{23}$

The theme of an eagle overcoming a snake is, in any case, a very ancient one, invariably with the same significance; it is represented, for example, on staters of Elis which controlled the great sanctuary of Olympian Zeus at Olympia, where an eagle is depicted flying with the snake coiled around it but firmly clasped in its beak, and on a silver didrachm of Acragas in Sicily dated to the late fifth century B.C., where it descends upon a writhing serpent. ${ }^{24}$ Dating from the Roman period, but in its fluidity of conception surely in a Hellenistic tradition, is the marble sculpture of an eagle standing upon and overpowering a writhing snake in the Naples Museum datable to the first century B.C. or early first century A.D. ${ }^{25}$ This is very much the type of the image on an intaglio moulded in light blue glass excavated from the site of St Martin-le-Grand, City of London. ${ }^{26}$ Among later second-century glyptic examples of the conflict of eagle with serpent are spirited renderings on a nicolo intaglio in a silver ring with a gold collet found near Wotton-underEdge and now in Gloucester Museum and a red jasper in the Ashmolean Museum of unknown provenance, both of second-century date and in both of which, as on our sculpture, the snake seems to rear up in order to face its adversary. ${ }^{27}$

The Augustan prototype for the eagle itself is encountered on coins, for instance a bronze quadrans of Augustus $c .10$ B.C. ${ }^{28}$ The type is equally familiar from many media including gems, such as an example from Ham Hill, Somerset; sometimes these intaglios are of the 'eagle-and-standards' type, exemplified by one from Hod Hill, Dorset — both of the mid-first century A.D. ${ }^{29}$ Of especial interest, as pointed out to me by Guy de la Bédoyère, is the eagle figured upon a painted panel from the House of the Vettii at Pompeii, where the eagle (which is somewhat sculptural in appearance) is perched on the altar overlooking the infant Hercules who is portrayed in the act of strangling two serpents. ${ }^{30}$ Although mythologised, the meaning is surely the same; Jupiter as the eagle, or here through his son Hercules, is portrayed as overcoming the evil forces of the world (FIG. 9c).

Of particular interest because they are from the North-Western provinces and from funerary contexts - probably both stood upon second-century burial mounds - are two sandstone statues of eagles with wings partially displayed, standing upon globes and at the same time overpowering serpents; both come from the Treveran region, respectively from Wederath and Siesbach im Hunsrück. ${ }^{31}$ The quality of the Minories sculpture, surely one of the very best pieces of Cotswold sculpture to have survived, must have graced an important tomb.

$C I L$ III, $7756=I D R$ III/5, 136.

I am grateful to Penny Coombe for suggesting emendations and for the translation.

Kraay and Hirmer 1966, 342 and pls 154-5, nos 489, 490 and 494 (Elis); 297 and pl. 65, no. 182 (Acragas).

Inv. no. 107814. Jashemski and Meyer 2002, 366, fig. 299.

Henig 2007, 211, pl. xxxi, no. App. 191.

Henig 1981, 130-1, pl. 8.1, no. 2; Henig and MacGregor 2004, 95, no. 9.96.

Mattingly 1923, 93, pl. 20, no. 1.

Henig 2007, 176, pl. xxi, no. 696 and 177, pl. xxii, no. 708.

Ling 1991, pl. viii A.

Haffner 1989, 409, Abb. 10; Wigg 1990, Taf. 70. 
Among other coin issues depicting eagles overpowering serpents, especially notable in our context is the group of small silver coins struck for the Atrebatic king Tincomarus, who was almost certainly a Roman client, in the late first century B.C. (FIG. 9d). These are unique, and without direct Roman prototype, in that the serpent rears up to face the eagle. ${ }^{32}$ Coins struck for two of his successors in southern Britain, Epaticcus and Caratacus, both depict an eagle and a snake, but here the eagles are shown more conventionally as already victorious over it. ${ }^{33}$ The political meaning of these coins is evidently the same as the well-known denarii struck by Julius Caesar which portray an elephant trampling a serpent. ${ }^{34}$ It is self-evident that in general terms the image likewise signifies good overcoming evil, or is a metaphor for the Roman Empire triumphing over barbarism. A similar meaning may be attached to gems which portray a bull above a serpent, such as the example from Tilurnum in Dalmatia in which the bull may represent a legion, probably VII Claudia pia fidelis or VII Augusta, both stationed in Dalmatia in the late first century B.C. and early first century A.D. ${ }^{35}$

The sculpture would appear to have come from a significant tomb, probably of Flavian date or a little later, in the important Minories cemetery. It is plausible, bearing the Atrebatic coins in mind, especially issues of Tincomarus, that it was actually a tomb of a member of his family. Bearing in mind its probable date, there might be a reference to the defeat of the Boudiccan revolt, for Togidubnus, the client king, and presumably the rest of the family were on the Roman side in the conflict. ${ }^{36}$ It is significant that the eagle was laid to rest very carefully in the ditch, which does not suggest any kind of damnatio memoriae.

This is one of the finest and earliest examples of work by a Cotswold sculptor to have come down to us. In quality it bears comparison with the Bath pediment to which allusion has been made above in connection with the representation of feathers. Hayward rightly draws attention to the spirited portrayal of a lion mastering a stag reused in the Camomile Street bastion which, although sadly battered, was clearly a magnificent piece. ${ }^{37} \mathrm{~A}$ third very impressive animal study is the seated boar from Bath, with its imaginatively patterned pelt and bristling mane, evidently a version of a late Hellenistic or Augustan prototype and most probably late first-century. ${ }^{38}$ Hayward additionally mentions two early tombstones of undoubted excellence, but these seem to me to be rather more formal productions, perhaps to be assigned to a military workshop. Other Cotswold works displaying comparable skill and originality appear to be later in date, among them the statue of Mercury from Uley, Gloucestershire, and the statue believed to portray Apollo Cunomaglos from Bevis Marks, London, both of which are of second-century date. ${ }^{39}$

\section{PETROLOGY OF THE SCULPTURE By K.M.J. Hayward}

Hand specimen and thin-section petrographic analysis was conducted during $2014^{40}$ and $2015^{41}$ in order to determine what type of limestone the eagle was made from and where possible to

\footnotetext{
32 Van Arsdell 1989, 142, no. 397; Hobbs 1996, 90-1, nos 880-905; Bean 2000, 151-2, nos Tin 3-5 and Tin 3-6, and pl. ix.

Van Arsdell 1989, 180, nos 580.1 and 580.3 (Epaticcus) and 183, no. 593.1 (Caratacus).

Creighton 2000, 121-2.

Middleton 1991, 116-17, no. 209.

Tacitus, Agricola 14.

Coombe et al. 2015, 69, no. 121.

Cunliffe and Fulford 1982, 18, no. 61 (but not a lion as stated there); Henig 1995, 85 and 87, illus. 55.

Henig 1993, 22, no. 62; Coombe et al. 2015, 44, no. 75.

On 4 June 2014 using a hand lens (Gowland $\times 10$ ) while in temporary storage at the Museum of London; results incorporated into the Corpus of Roman Sculpture for London and the South-East (Coombe et al. 2015, 124-6, no. 229).

${ }_{41}$ Two $<1 \mathrm{~cm}$ samples were taken mechanically using a hammer and chisel from the right bottom back area of the statue. Thin section MNR 12 [569] < 118> was produced January 2015 via Quaternary Scientific (Quest) using the thin
} 


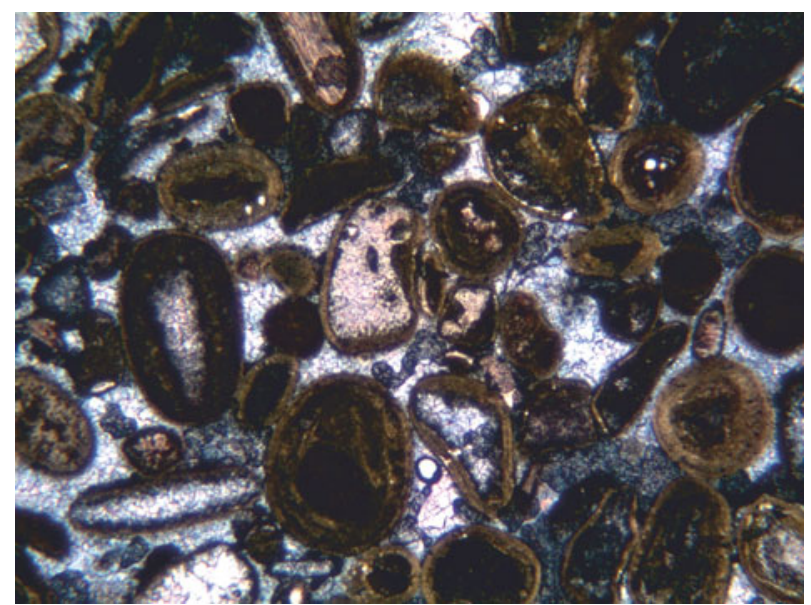

FIG. 10. Photomicrograph showing textural, chemical and palaeontological character of the limestone eagle and serpent $<\mathrm{S} 1>$. Cross Polarised Light. Stained Alizarin Red C and Potassium Hexocynoferrate to pick out variability in colour between ferroan and non-ferroan calcite (field of view $4.8 \mathrm{~mm}$ ).

determine its geological source. Initial visual inspection of the sculpture determined that it was carved from oolitic limestone (shelly) of the south Cotswolds. In hand specimen, the sculptural surface of this hard fine cream-white $(2.5 \mathrm{Y} 8 / 1)$ to pale-yellow $(2.5 \mathrm{Y} 8 / 2)$ limestone is pitted with small $(0.5-1 \mathrm{~mm})$ hollowed ooids together with yellow and grey oyster fragments, and very occasional pink ferroan calcite that belonged to echinoid plates and a small calcite vein or watermark. Together, these features are characteristic of building stones from the Middle Jurassic (Bathonian) limestone scarp face of the south Cotswolds, specifically between Cirencester and Bath.

In order to reinforce and refine characterisation, a prepared thin-section (FIG. 10) of the limestone was compared with a petrographic reference collection of slides obtained from 150 freestone outcrop samples and early Roman sculptural samples collated from earlier research. ${ }^{42}$

A photomicrograph (FIG. 10) of the section not only verifies a bio-oosparite limestone ${ }^{43}$ from a south Cotswold Middle Jurassic source but illustrates some important textural, chemical and palaeontological similarities with samples taken from other examples of religious and funerary sculpture from late first-century London and Cirencester prepared and analysed in this way. In particular, it bears a striking petrological affinity with the rock used in a tombstone of a Flavian-Trajanic officialis ${ }^{44}$ and part of a probable early funerary sculpture depicting a lion overcoming a stag, ${ }^{45}$ both from Arthur Price's 1876 excavations ${ }^{46}$ near Bastion 10. Similarly, the material is comparable to the Claudio-Neronian Sextus Valerius Genialis auxiliary tombstone from Cirencester. ${ }^{47}$ Like the eagle, these three examples have the same round ooids coated in a thick brown iron oxide matrix, a high blue-ferroan content and fine microcrystalline

section preparation facilities at the School of Archaeology, Geography and Environmental Science (SAGES) at the University of Reading.

42 Hayward 2006; 2009; 2015a.

43 Folk 1959; 1962.

44 Coombe et al. 2015, 47-8, no. 80, pls 44-5; Bishop 1983.

45 Coombe et al. 2015, 69, no. 121, pl. 55.

46 Price 1880.

47 RIB I, 109; Henig 1993, 45, no. 137, pl. 35. 
cement, indicating a common source. The closest match is to Bibury stone, just 6 miles east of Cirencester.

This material is by far the most common stone type in use in late first- to second-century religious and funerary sculpture in London, having been identified in 40 examples, ${ }^{48}$ as well as at sites closer to the source along the Jurassic ridge at Cirencester. What is particularly interesting is how similar its petrology is to a small group of high-quality early funerary monuments from London which were reused nearby in Bastion 10. The golden yellow lion overcoming a $\operatorname{stag}^{49}$ is probably only second in terms of its stylistic quality to the eagle and also depicts a similar scene of the ravening power of death. As a group these materials would have adorned the extensive cemeteries to the east of the Roman city of London.

In light of recent research into the petrological and geochemical character and source of mid-first- to early second-century tombstones, architectural fragments and religious sculpture from London, ${ }^{50}$ south-central Britannia, ${ }^{51}$ Germania Inferior ${ }^{52}$ and Aquileia, ${ }^{53}$ we are beginning to understand more about the range of materials in circulation at the time that this sculpture was being carved. ${ }^{54}$ As is the case elsewhere in London and Colchester, the best quality limestones, including golden yellow and white continental and native freestones, were used early on in the province's development. These materials also provided some of the best examples of carving at any time during the province's history. The need to display and mimic white polished marble in high-quality native and continental Jurassic limestone is a theme revisited time and time again in funerary sculpture from London and south-east England. It also shows just how much was known about the extent and detail of the Middle Jurassic Freestone resource so soon after the conquest. The eagle merely represents the finest example, so far, of this group from London. ${ }^{55}$

\section{DISCUSSION}

The exquisitely carved statue of the eagle and serpent represents one of the finest and earliest examples of freestone ${ }^{56}$ sculpture from the London cemeteries and indeed from Roman London. ${ }^{57}$ Its burial in the roadside ditch suggests that the high-status tomb or mausoleum in which it was housed was located on or close to the site. To date, few first-century structures of either wooden or masonry construction have been found. ${ }^{58}$ At the nearby site of 9 St Clare Street a late first- to early second-century inhumation burial may be contemporary with an adjacent stone-lined tomb, though this was undated..$^{59}$ The majority of these structures are dated post-A.D. 120, though the existence of earlier monuments is inferred from architectural and sculptural fragments found residually in second-century contexts, such as the fragments of inscribed marble slabs from 9 St Clare Street. ${ }^{60}$

Coombe et al. 2015.

Coombe et al. 2015, no. 121.

Hayward 2015a.

Hayward 2006; 2009.

Stribrny 1987.

Maritan et al. 2003.

Hayward 2015a.

Hayward 2015b.

An even-grained, soft, open porous limestone or sandstone enabling the rock to be worked or carved in any direction (Leary 1989).

Hayward 2015b.

58 Barber and Bowsher 2000, 111-12.

59 Ellis 1985 (site code SCS83).

60 ibid. 
The burial of funerary and religious sculpture is a phenomenon that is well documented in the London area. A group of stone sculptures including fragments of an altar, a tombstone, three deities and a small stone chest topped with a reclining female figure was recovered from a late Roman well under Southwark cathedral. ${ }^{61}$ The pieces probably derived from a funerary mausoleum and signs of burning on one of the pieces and the possible mid-fourth-century date of their deposition may have been the result of Christian iconoclasm. ${ }^{62}$ An example more pertinent to the Minories eagle comes from the group of oolitic limestone sculpture found within a roadside ditch within a walled cemetery along Great Dover Street in Southwark. ${ }^{63}$ The bearded head, possibly of a river god, and a moulded stone cornice probably adorned one of the funerary monuments which had fallen into disrepair by the third century. ${ }^{64}$ In both these instances, it seems that the monuments which housed them were destroyed or were no longer in use.

The cemetery area in the site and its environs does not appear to have been densely exploited in the first and second centuries. Since the need to release space for new interments does not seem to have been the determining factor, it is not clear why the mausoleum would have been destroyed. Given the condition of the Minories eagle and the fairly short time from when the sculpture was carved to its deposition in the ditch, perhaps an alternative explanation for its burial should be sought. The remains of the mausoleum may await discovery close to the site but ultimately it is not possible to determine the circumstances behind the burial of the sculpture.

\section{SUPPLEMENTARY MATERIAL: CONTENTS}

For supplementary material for this article please visit https://doi.org/10.1017/S0068113X17000010.

Note: the Supplementary Material includes ONLINE FIGS 1-14 and Tables 1-2.

SECTION 1: Introduction: the site and its setting D1-2

SECTION 2: First-century A.D. land use and the establishment of the cemetery road c. A.D. 50-100 (Periods 1 and 2) D3-5

SECTION 3: Second-century development of the site c. A.D. 100-60 (Period 3) D5-11

SECTION 4: The late second-century development of the roadside cemetery A.D. 160-400 (Period 4) D11-13

SECTION 5: Discussion D13-14

Bibliography D19

\section{ACKNOWLEDGEMENTS}

Museum of London Archaeology (MOLA) would like to thank Scottish Widows Investment Partnership Property Trust and its development partner Endurance Land for generously funding the fieldwork, post-excavation analysis and publication of this site and McAleer \& Rushe for their support throughout the fieldwork. We would also like to thank Kathryn Stubbs (Assistant Director Historic Environment, City of London) for assistance and guidance throughout the project. Thanks are also due to Simon Davis the MOLA site Project Officer and the MOLA field team for their efforts on site. MOLA project management

61 Hammerson 1978.

62 ibid.

63 Mackinder 2000

64 Blagg 2000, 61-3. A pine-cone finial and a cornice moulding were also recovered from inside one of the structures. 
was undertaken by Louise Davies and post-excavation management by David Bowsher. Thanks to the following MOLA specialists for their contributions to the post-excavation programme: Charlotte Burn (pottery), Angela Wardle and Michael Marshall (accessioned finds), Ian Betts (building material), Don Walker (osteology), Alan Pipe (faunal remains) and Karen Stewart (botany). The graphics were produced by Sarah Jones and Carlos Lemos and the photography by Andy Chopping. Martin Henig would particularly like to thank Penny Coombe and Francis Grew for discussing the sculpture with him, and also Alan Pipe for suggesting the species of eagle represented here. Gratitude is expressed to Csaba Szabó and Guy de la Bédoyère for providing references which help to elucidate the meaning of the image. Kevin Hayward would like to thank John Jack (SAGES), University of Reading, for the preparation of the petrological section.

Museum of London Archaeology (A.L.)

alerz@mola.org.uk

University of Oxford (M.H.)

martin.henig@arch.ox.ac.uk

Pre-Construct Archaeology Ltd (K.H.)

khayward@pre-construct.com

\section{BIBLIOGRAPHY}

Barber, B., and Bowsher, D. 2000: The Eastern Cemetery of Roman London: Excavations 1983-90, MoLAS Monograph Series 4, London

Bean, S.C. 2000: The Coinage of the Atrebates and Regni. Studies in Celtic Coinage 4, Oxford University School of Archaeology Monograph 50, Oxford

Beeson, A. 2003: 'From Petra to Keynsham - a Romano-British sculpture and its iconographical origins', The Bulletin of the Association for Roman Archaeology 14, 10-13

Beeson, A. 2014: 'The flight to the heavens - the Minories eagle', Association of Roman Archaeology News $31,20-2$

Bishop, M.C. 1983: 'The Camomile Street solider reconsidered', Transactions of the London and Middlesex Archaeological Society 34, 31-48

Blagg, T.F.C. 2000: 'Sculptures and architectural fragments', in Mackinder 2000, 61-3

Blagg, T.F.C. 2002: Roman Architectural Ornament in Britain, BAR British Series 329, Oxford

CIL: Corpus Inscriptionum Latinarum (1863-)

Coombe, P., Grew, F., Hayward, K., and Henig, M. 2015: Corpus Signorum Imperii Romani. Great Britain 1 Fascicule 10. Roman Sculpture from London and the South-East, Oxford

Creighton, J. 2000: Coins and Power in Late Iron Age Britain, Cambridge

Cunliffe, B., and Davenport, P. 1985: The Temple of Sulis Minerva at Bath. I. The Site, Oxford University Committee for Archaeology Monograph 7, Oxford

Cunliffe, B.W., and Fulford, M.G. 1982: Corpus Signorum Imperii Romani. Great Britain 1 Fascicule 2. Bath and the Rest of Wessex, Oxford

Durham, E. 2013: 'Symbols of power: the Silchester bronze eagle and eagles in Roman Britain', Archaeological Journal 170, 78-105

Ellis, R. 1985: 'Excavations at 9 St. Clare Street', London Archaeologist 5, 115-21

Folk, R.L. 1959: 'Practical petrographic classification of limestones', American Association of Petroleum Geologists Bulletin 43, 1-38

Folk, R.L. 1962: 'Spectral subdivision of limestone types', in W.E. Ham (ed.), Classification of Carbonate Rocks, American Association of Petroleum Geologists Memoir No. 1, Tulsa, 62-84

Glueck, N. 1966: Deities and Dolphins. The Story of the Nabataeans, London

Haffner, A. 1989: Gräber, Spiegel des Lebens: Zum Totenbrauchtum der Kelten und Römer am Beispiel des Treverer-Gräberfeldes Wederath-Belginum, Mainz

Hammerson, M. 1978: 'Excavations under Southwark Cathedral', London Archaeologist 3 (8), 206-12

Hayward, K.M.J. 2006: 'A geological link between the Facilis monument at Colchester and first-century army tombstones from the Rhineland frontier', Britannia 37, 359-63 
Hayward, K.M.J. 2009: Roman Quarrying and Stone Supply on the Periphery - Southern England. A Geological Study of First-century Funerary Monuments and Monumental Architecture, BAR British Series 500, Oxford

Hayward, K.M.J. 2015a: 'Types and sources of stone', in Coombe et al. 2015, 34-46

Hayward, K.M.J. 2015b: Statue of an Eagle and Serpent from London: The Petrology, unpub. MOLA archive report

Henig, M. 1981: 'Continuity and change in the design of Roman jewellery', in A. King and M. Henig (eds), The Roman West in the Third Century. Contributions from Archaeology and History, BAR International Series 109, Oxford 1981, 127-43

Henig, M. 1993: Corpus Signorum Imperii Romani. Great Britain 1 Fascicule 7. Roman Sculpture from the Cotswold Region, with Devon and Cornwall, Oxford

Henig, M. 1995: The Art of Roman Britain, London

Henig, M. 2007: A Corpus of Roman Engraved Gemstones from British Sites, BAR British Series 8 (3rd edn), Oxford

Henig, M., and MacGregor, A. 2004: Catalogue of the Engraved Gems and Finger-rings in the Ashmolean Museum. II. Roman, BAR International Series 1332, Oxford

Hobbs, R. 1996: British Iron Age Coins in the British Museum, London

Huskinson, J. 1994: Corpus Signorum Imperii Romani. Great Britain Fascicule 8. Roman Sculpture from Eastern England, Oxford

IDR III, 5: Inscriptiones Daciae Romanae: Apulum Daciae Superioris I, Piso, Académie des Inscriptions et Belles-lettres (2001)

Jashemski, W.F., and Meyer, F.G. 2002: The Natural History of Pompeii, Cambridge

Kraay, C.M., and Hirmer, M. 1966: Greek Coins, London

Leary, E. 1989: The Building Limestones of the British Isles, London

Lerz, A., with Betts, I., Blackmore, L., Bowsher, J., Pearce, J., Pipe, A., Richardson, B., and Stewart, K. forthcoming: 'Further evidence for the Abbey of St Clare and later occupation at 24-26 Minories EC1', Transactions London and Middlesex Archaeological Society

Ling, R. 1991: Roman Painting, Cambridge

Mackinder, A. 2000: A Romano-British Cemetery on Watling Street. Excavations at 165 Great Dover Street, Southwark, London, MoLAS Archaeology Studies Series 4, London

Maloney, J. 1983: 'Recent work on London's defences', in J. Maloney and B. Hobley (eds), Roman Urban Defences in the West, CBA Research Report 51, London, 96-117

Maritan, L., Mazzoli, C., and Melis, E. 2003: 'A multidisciplinary approach to the characterisation of Roman gravestones from Aquileia (Udine, Italy)', Archaeometry 45 (3), 363-74

Marsden, P.R.V. 1980: Roman London, London

Mattingly, H. 1923: Coins of the Roman Empire in the British Museum. I. Augustus to Vitellius, London

Middleton, S.H. 1991: Roman Gems from Dalmatia, Oxford

Perring, D. 1991: Roman London, London

Price, J.E. 1880: On a Bastion of London Wall, or, Excavations in Camomile Street, Bishopsgate, London, London

RIB I: The Roman Inscriptions of Britain. I. Inscriptions on Stone, R.G. Collingwood and R.P. Wright (eds), Oxford (1965); reprinted with Addenda and Corrigenda by R.S.O. Tomlin, Stroud (1995)

RIB III: The Roman Inscriptions of Britain. III. Inscriptions on Stone found or notified between 1 January 1955 and 31 December 2006, R.S.O. Tomlin, R.P. Wright and M.W.C. Hassall (eds), Oxford (2009)

Stribrny, C. 1987: Corpus Signorum Imperii Romani. Deutschland. II, 8 Germania Superior. Die Herkunft der römischen Werksteine aus Mainz und Umgebung. Vergleichende petrographische und geochemische Untersuchungen an skulptierten Kalksteinen, Bonn

Tacitus: Gaius Cornelius Tacitus, Agricola, Germania, Dialogus, Loeb Classical Library edition, trans. M. Hutton and W. Peterson, rev. R.M. Ogilvie, E.H. Warmington and M. Winterbottom, Cambridge, Mass./London (1914)

Toynbee, J.M.C. 1971: Death and Burial in the Roman World, London

Van Arsdell, R.D. 1989: Celtic Coins of Britain, London

Wigg, A. 1990: 'Die steindenkmalreste des römerzeitlichen Grabhügels bei Siesbach im Hunsrück', Archäologisches Korrespondenzblatt 20, 453-61 